\title{
Locus of control of English philology undergraduates
}

\author{
PAULINA OGÓREK \\ ADRIANA BIEDROŃ
}

Received 31.04.2020,

received in revised form 28.10.2020,

accepted 9.11.2020.

\begin{abstract}
The concept of locus of control shows the relationship between events and people's reactions to them, depending on whether they attribute their outcomes to internal or external factors. Accordingly, people can be divided into two main groups. Those who feel personally responsible for what happens to them are labelled internals, whilst those who believe that external forces such as fate, luck or objective difficulties determine their life are termed externals. This paper presents the results of a study conducted on 41 English philology undergraduate participants with a view to investigating their locus of control, that is, whether they perceive their academic outcomes as the result of their skills and abilities or rather fate or luck, in other words, if they feel personally responsible for their academic successes and failures.
\end{abstract}

\section{Keywords}

locus of control, second language acquisition, academic achievement, attribution theory 


\title{
Poczucie umiejscowienia kontroli wśród studentów filologii angielskiej
}

\begin{abstract}
Abstrakt
Pojęcie poczucia umiejscowienia kontroli pokazuje relację pomiędzy zdarzeniami a reakcjami na te zdarzenia zależącymi od tego, czy ludzie przypisuja ich wyniki czynnikom wewnętrznym, czy zewnętrznym. Konsekwentnie, ludzie dzielą się na dwie główne grupy. Osoby, które czuja się odpowiedzialne za to co się im przydarza, określane są mianem wewnatrzsterownych, zaś ci, którzy wierza, że ich życie determinuja czynniki zewnętrzne, takie jak przeznaczenie, szczęście czy obiektywne przeciwności, definiuje się jako zewnatrzsterownych. Artykuł prezentuje wyniki badania przeprowadzonego na 41 studentach filologii angielskiej, którego celem było zbadanie ich umiejscowienia kontroli, to znaczy, czy postrzegaja oni swoje oceny akademickie jako wynik zdolności i umiejętności, czy też przypisuja je przeznaczeniu lub przypadkowi, innymi słowy, czy czują się odpowiedzialni za swoje sukcesy i porażki.
\end{abstract}

\section{Słowa kluczowe}

poczucie umiejscowienia kontroli, akwizycja języka drugiego, osiagnięcia akademickie, teoria atrybucji

\section{Introduction}

The term locus of control (LOC) is strongly connected with people's perception of the outcomes of their actions - whether they put their faith in destiny or attribute success/failure to their own decisions. The term was coined by Julian Rotter, who stated that individuals' previous experience is the major force that influences the level of individuals' feeling of being responsible for their own efforts (1966: 2). Rotter also emphasized the role of reinforcement or prize in building attributions. However, not uncommonly, an event recognized by one person as a sort of gratification or reward will be interpreted by another in 
a completely different way. There may be many factors responsible for such a reception, among which the level of personal belief about having control over life events, in contrast to external forces that are uncontrollable, comes to the fore. This leads to a division described by Rotter as internal and external control. The loci of an individual (plural of locus, which in Latin means "location" or "place") are presented as internal or external (Williams and Burden 1997: 101). This division is especially important in second language acquisition (SLA). Research in the attributional field seems to provide evidence that internal LOC, in other words, perceiving outcomes as within one's control, is directly related to academic achievement (Williams and Burden 1997). Biedron's study from 2003 (see also 2008) suggests that English philology students who attribute their academic outcomes to internal factors are more persistent, hardworking, able to maintain motivation, and therefore more successful than their more externally oriented counterparts. Having analysed the attributional reactions of English philology students, she found that they are internals, which means that they feel responsible, perceiving the causes of events in their efficient or inefficient trials. LOC is not a stable trait, but a changeable, situational characteristic that can be altered in a way that will enable learners to take control over their own learning. Seventeen years after Biedron's study we decided it is time to investigate whether modern English philology students are the same or different in terms of their LOC as the students 17 years ago. To this end, a study was conducted on 41 English philology undergraduates in order to evaluate their controllability profile, that is, whether they believed that their academic outcomes depended on their own effort or rather on uncontrollable factors.

\section{Locus of control}

People with an internal LOC, internals for short, have a strong faith in their own skills and personal abilities. Their behaviour is considered "instrumental" (Carver 1976: 358), which means 
that they focus mostly on having important tasks completed at all costs. Additionally, this goal-oriented behaviour is often favoured over congenital reactions (Patterson 2018: 77). Internals believe in their skills and abilities during tests and examinations. The more ambitious their goals are, the more strongly they believe that a positive outcome depends on their abilities, and not on some external forces. Such students highly evaluate their opportunities of receiving better grades, and later graduating and proceeding to another educational institution with higher educational standards and prestige (Biedron 2008: 68).

On the other hand, people with an external LOC, (externals), do not assume that their actions will bring about any noticeable effect. Since they think that they have no influence on the world around them, externals do not change their behaviour, even if such an adaptation would impact the final result: "[...] if a person perceives the outcome of his actions as situated beyond his control the outcome stops determining behavior" (Biedron 2008: 67). Externally-oriented people believe that they have no control over the events taking place in their lives, assuming that their entire existence is controlled by powerful external forces that are difficult to oppose.

Externals are not a homogenous group. In their research, Wong and Sproule (1984) divided them into three subgroups. The first type, a passive external, is an individual who generally lacks motivation for gaining achievements. Such a person believes in their lack of control over events, considering the world to be a bitter, hateful place (Wong and Sproule 1984: 318). The second type is a defensive external, who may not vary from internals when it comes to achievement motivation. Such an individual associates failures with external forces, and as a result is freed from guilt and responsibility. Very high ego-defensive mechanisms are also the main part of his/her overall behaviour. The last type is a realistic external. His/her choices are inspired more by real life and immediate surroundings rather than higher values. A realistic external is aware of the limits of his/her control and refuses to see the world through rose-tinted 
glasses. He/she perceives the world as being full of dilemmas and struggles, all of which are beyond his/her control, yet such an approach does not render him/her a desperate, helpless, or incompetent creature (Wong and Sproule 1984: 319). He/she wants to achieve some realistic goals, which positions him/her somewhere in between the two extremes of idealistic-optimistic controllers and unrealistic-pessimistic controlees (Biedroń 2008: 72).

\section{Rotter's I-E scale}

Variations in externality/internality of control and people's expectations in relation to the level of their control over certain aspects of life gave rise to different measurement instruments. A classical tool is Rotter's (1966) Internal-External scale for measuring LOC, the I-E scale for short. It is a questionnaire consisting of 29 elements, based on Phares' study from 1957. The participants' task is to select the most suitable answers about the origins of a human's failure, namely, determine whether the misfortune is associated with the individual's misdeeds, and hence internal, or if the lack of success is caused by external elements. The questions are focused on the participants' beliefs about the possible ways of commanding and controlling involvement, which made this test a basic tool for evaluating the externality/internality of control (Rotter 1966: 10). When the results obtained from the use of Rotter's I-E scale were examined, an interesting relationship emerged, which seems to confirm the explanation of the term "control", provided earlier. The aforementioned results, described by Davis and Davis in 1972 and Phares, Wilson and Klyver in 1971 (Wong and Sproule 1984: 317), clearly showed the internal participants as much more determined than the externals, especially in situations when they became intentionally responsible for all activities that they were engaged in. Additionally, people classified as internals, according to Rotter's I-E scale, are more competent in taking control during action than their external counterparts. 
Internality of control is also interpreted as an eagerness to possess more actual, sometimes even personal, command over a task.

\section{Attribution theory}

While discussing Rotter's LOC theory, it is impossible not to mention the whole concept of the attribution theory, which started a body of research into human perception of control and causality. The very first steps in this field were made by Heider (1958) and the concept was further developed in the works of Harold Kelley and Bernard Weiner. Kelley described the attribution theory as "a theory about how people make causal explanations, about how they answer questions beginning with "why?". It deals with the information they use in making causal inferences, and with what they do with this information to answer causal questions" (1973: 107). He also suggested that people make certain attributions under specific circumstances, and that statement led him to differentiate between two main situations in which the attribution process is carried out. In the first, there are cyclical events with a more or less fixed frequency of occurrence, while in the second situation, the events are single, random occurrences. According to Kelley, people will adopt different patterns and standards to make specific attributions for both situations.

In 1985, Bernard Weiner presented a variation of attribution theory, calling it "an attributional theory of motivation and emotion, with achievement strivings as the theoretical focus" (Weiner 1985: 549). He began by identifying the main phenomena that contributed to success or failure, which are associated with achieving high results and various types of accomplishments. The theory was grounded on presenting an individual's striving for achievement with emotions and personal motivation as significant moderators. To define this issue more precisely, Weiner described two studies in which he intended to observe what explanations would be given by the subjects to explain the 
results of certain actions. In the first case, only information about the success or failure of a given action was provided to the respondents. Their task was to give causal explanations of the outcome in their own words, using all possible options that appeared in their minds. In contrast, the second group of respondents was provided with a list of causes, and their task was to match the causes to the outcome and assess their impact on each of the final results. After collecting and analysing the answers given, it became apparent that in both groups the causes that, according to the respondents, had the greatest impact on success and failure were the efforts put in the task, and the abilities and skills possessed by the people involved: "that is, success is ascribed to high ability and hard work, and failure is attributed to low ability and absence of trying" (Weiner 1985: 549). These conclusions proved to be universal for most cultures and communities all over the world. The number of causes given by respondents is almost infinite, yet people usually attribute success to hard work and motivation and identify failure with the absence of those two elements. Weiner's research guided him towards a causal structure, which was first distinguished by Fritz Heider in 1958: "In common-sense psychology (as in scientific psychology) the result of an action is felt to depend on two sets of conditions, namely factors within the person and factors within the environment" (Heider 1958: 82, as cited in Weiner 1985: 551).

Weiner's theory presents an attributional process organized within three universal dimensions that influence individual decisions. These dimensions are as follows:

1. Locus of causality (internal - external)

2. Stability (stable - unstable)

3. Controllability (controllable - uncontrollable).

The first dimension of internality/externality is comparable to Heider's (1958) fundamental distinction between internal and external factors. The second dimension was introduced since 
among all internal causes some evolve and change, while others remain permanent and stable. For instance, the competence to perform certain tasks is considered to be something relatively stable, while the energy put into the work and the individual's state of mind are treated as factors which are more changeable and flexible. The same criterion can be applied to causes commonly considered external. Examination results, regardless of whether they represent a positive result or grave failure, may be connected with the assessment method that a school has, which is a stable and unchangeable norm or they can be attributed to one's luck or lack thereof during risky behaviours in the exam such as guessing the answers, which is a fluctuating external cause (Biedron 2008: 78). The third level is the range within which an individual is able or unable to control certain elements in the attribution process. It is called the controllable-uncontrollable dimension and is used for all elements in the attribution (Munton 1999: 20). It results from Rotter's research and his distinction between internal causes that can be controlled in some way and external ones that are beyond control. Among the internal and, at the same time, unstable factors, we can distinguish the mood of a person while performing a task, as well as their tiredness and efforts lasting for a short time. Yet, among those three factors, effort is something dependent on the will of the individual - the subject can boost the amount of effort they use or reduce it. The same rule does not work for mood or tiredness, which, generally, cannot be changed by the subject's will. Similar distinctions were found among causes classified as internal and rather stable - laziness and sloppiness are considered to be subject to deliberate and conscious control, while aptitude, which is internal and stable as well, is not subject to this type of control (Biedroń 2008: 79). 


\section{LOC and academic achievement in second language acquisition}

Attribution theory applies to academic achievement and learning, and so does the LOC theory. The advantages of having an internal LOC far outweigh its associated drawbacks. The areas of life in which being internal is extremely helpful include solving various tasks, studying, and pursuing set goals. They also include successes in learning or in academic life and hence - in academic achievement. People with internal LOC have more faith in their own abilities, which is related mainly to achieving success and, consequently, to a greater possibility of progress in the future.

The studies conducted on students (Biedron 2008, Kutanis, Mesci and Övdür 2011) indicated that they usually have an internal LOC, which is favourable for personal development in the field of study. The cooperation between the student and the teacher also influences the behaviour associated with achieving success. People who declare themselves to be internals have higher requirements, higher ambitions, and reveal behaviours that are favourable to high achievements, such as searching for information in scientific sources, seeking contacts with professionals or taking part in educational, developing activities (Strickland 1977, as cited in Blass 2015: 237). The previously described striving for achievement in combination with the LOC has an impact on SLA. A few studies were conducted in order to investigate the correlation between language learning and LOC (Biedroń 2008, Gałąza and Trinder 2016).

The study conducted by Biedron $(2003 ; 2008)$ concerned the extent to which students believe that they have an impact on certain factors related to the learning of a second language and how students are able to control these factors. This study was conducted on a group of 40 relatively young students (19 to 25 years old). The majority of the participants were identified as internally-oriented autonomous learners. In the case of LOC, many of the respondents believed that they were able to 
completely or at least partially control their skills and abilities. It was interesting that a large number of respondents recognized the difficulty of a given task as something that they are able to control. This could be related to the possible freedom of selecting the task that the student has to solve. If a person chooses an exercise suited to his/her skills and knowledge, then he or she may consider the difficulty of the exercise to be a controllable factor (Biedron 2008: 113). Not surprisingly, the results looked similar when it came to the time that the students spent on learning and the level of effort they put into it. Believing that they have an influence on how they organize their learning process, the respondents considered both factors to be under their control. What is more, the students attributed a role to their interest: If they were interested in the subject, they were able to produce better results. As far as the level of proficiency in English is concerned, the students believed that they had an impact on how much competence in the language they were able to achieve.

Gałazka and Trinder did not find much support for the hypothesis in their study, in which they sought to answer the question about the relationship between the LOC and the achievements gained while learning a second language. From their perspective, an insufficient number of respondents contributed to the lack of expected results, and the results which were obtained had an insignificant statistical value. Their findings did not show LOC as a factor by which the skills of individuals (especially those related to SLA) could be assessed. (Gałazka and Trinder 2016: 139).

Nonetheless, most of the available research results show that the level of the internal LOC among university students is very high. Moreover, even the factors that are objectively difficult to control, such as language skills or difficulty of the tasks received, were also considered controllable. All this means that people who are proficient in a foreign language, that is good language learners, also reveal a high level of confidence in their 
own abilities, which is characteristic of the internal LOC (Biedroń 2008: 114).

\section{Undergraduates and their LOC}

\subsection{The study objectives}

The main objective of the presented research was to identify which kind of LOC is prevalent among English philology graduates - how they perceive the world and different events in life, and whether they think that their skills or choices influence their outcomes. Specifically, the results of the research were analysed in terms of students' LOC in relation to learning English.

The study was conducted with 41 English philology undergraduates, both male and female, from the first and second grade studies. Most of them studied at the Pomeranian Academy in Słupsk, yet due to the fact that the test was carried out in an electronic form, a few students from universities in Gdańsk and Kraków also volunteered to participate. The respondents were of different ages - the youngest were 23, while the oldest was over 45 years old. The amount of time they had studied English also varied, ranging from 6 years to 16 or more. Most participants gave their consent to participate in the study, yet some of them were volunteers interested in the study results. The questionnaire was anonymous and the participants were not subject to pressure at any time during the procedure. They were asked to give honest answers. The participants were chosen for the test as a result of the profile of their studies - it was assumed that those who had graduated from English philology represented a high level of proficiency, linguistic awareness, and learning autonomy.

\subsection{Data collection techniques}

The questionnaire was created using Google Forms (appendix A). People willing to take the questionnaire received a link sent 
via various messenger apps or e-mails, which led to the questionnaire's website. The questionnaire consisted of three parts. The first was the original Rotter's I-E scale test (1966), which allowed the researcher to check which of the two options better suited the respondents. This test consisted of 29 closed questions with one possible answer per question. The answers allowed the researcher to analyse whether the students were more internally or externally oriented.

The second part of the study was intended to check the respondents' opinion about the control of certain behaviours or circumstances occurring in the process of learning a second language. A concise questionnaire, originally suggested by Williams and Burden (1997: 110), was used to verify the levels of control among the students (appendix B). The survey consisted of eight closed, single-choice questions. Among the available answer options were, among others, the time needed for learning, the difficulty of a given task, skills and interest in the subject.

In the third part, the respondents were asked to provide basic biographical information as well as the length of time they had been learning English (appendix C). Additionally, the decision was made to interview two people who had agreed to share their experiences regarding language learning. During the interview, they also referred to the subject of the survey, explaining why they chose their particular answers, and what was important to them in language learning.

\subsection{Results}

\subsubsection{Questionnaire}

The questionnaire was assessed using Rotter's original I-E scale to define whether the students had a more internal or external LOC. The participants responded to 29 questions, 6 of which were "fillers". The number of points from the whole test was later added up. The higher the result, (the closer to 23), the more 
externally-oriented the subject was considered to be. The lower the score, the higher the level of internal LOC was assumed.

The test results were collected and analysed. The obtained data, however, indicated that it was not possible to clearly determine if the group was more internally or externally oriented. Twenty three questions were taken into consideration. The average score was 12.05 out of 23 points, with an average score of 11.83 for women and 12.21 for men, respectively. After rounding to a whole number, the score was 12 , both for females and males. None of the subjects taking the test was a typical external, whose score would be closer to 23 points, yet also no one turned out to be highly internal with a score approaching zero points. This means that the students on average were somewhere in the middle of the externality-internality continuum.

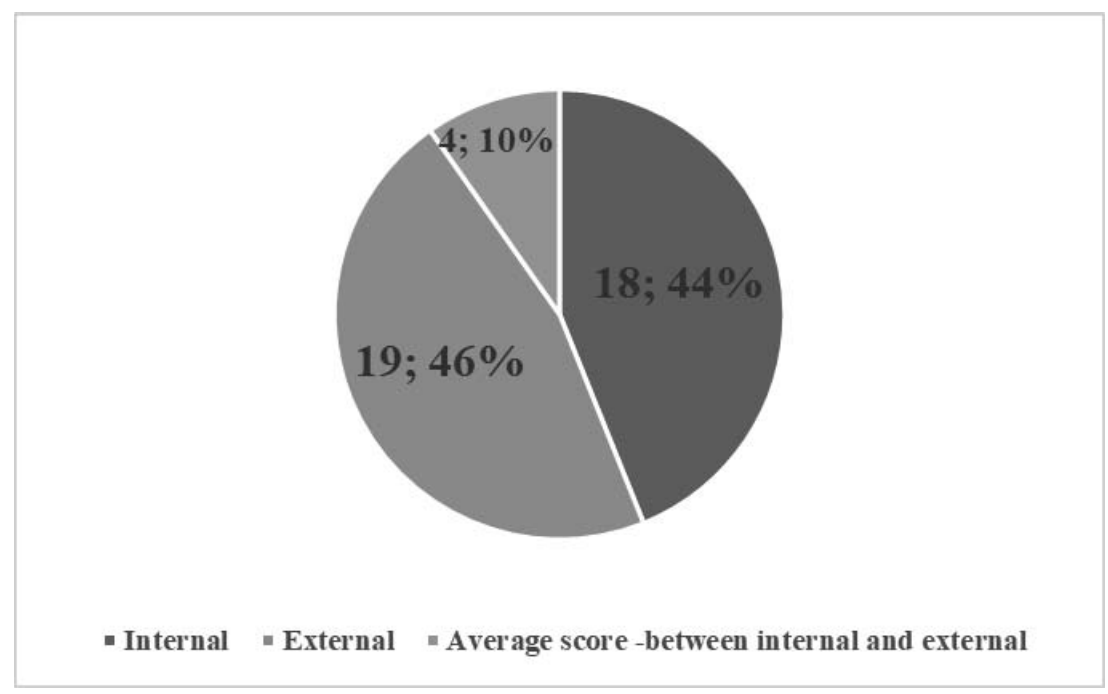

Figure 1

The results of the study - an even distribution of scores is visible 
Considering the LOC, the results were quite interesting, as values were distributed evenly. For eighteen (44\%) people, the survey result was below half and totalled 11 or less. These people more often scored on the internal LOC questions, when referring to their own skills and abilities. Among them, eight $(44 \%)$ were women and ten (56\%) men. Four people (10\%), one woman and three men, scored 12 points, a score which places them somewhere in the middle. They chose the answers indicating the personality traits characteristic for internals, yet they also sometimes tended to choose options typical of externals, such as those associated with believing in destiny or in external forces that control the world.

Nineteen (46\%) people who scored 13 points, a little above the average score, were classified as those exhibiting traits typical for externals. Furthermore, among this group, gender did not appear to have much significance in the selection of answers, as there were nine (47\%) women and ten (53\%) men.

\subsubsection{Controllability in SLA}

The results from the second part of the survey, connected with the controllability dimension in SLA are presented below. The test itself was a table in which the respondents had to indicate which of the presented factors they considered to be under their control in comparison with those which were beyond their reach while learning a second language.

The results of the survey clearly indicate that the respondents considered their own abilities to be under their own control. Twenty (48.8\%) people said that they were often able to control their abilities, yet as many as fifteen (36.5\%) thought they were always able to do it. This is difficult to interpret as it seems evident that people are not always able to control their skills, not to mention their abilities, due to a variety of different reasons. 
Table 1

The results of controllability in second language learning

\begin{tabular}{|l|c|c|c|c|}
\cline { 2 - 5 } \multicolumn{1}{c|}{} & ALWAYS & $\begin{array}{c}\text { QUITE } \\
\text { OFTEN }\end{array}$ & $\begin{array}{c}\text { NOT } \\
\text { OFTEN }\end{array}$ & NEVER \\
\hline 1. Your ability & $\begin{array}{c}15 \\
(36.5 \%)\end{array}$ & $\begin{array}{c}20 \\
(48.8 \%)\end{array}$ & $4(9.8 \%)$ & $\begin{array}{c}2 \\
(4.9 \%)\end{array}$ \\
\hline $\begin{array}{l}\text { 2. The difficulty of } \\
\text { the task }\end{array}$ & $\begin{array}{c}8 \\
(19.5 \%)\end{array}$ & $\begin{array}{c}17 \\
(41.5 \%)\end{array}$ & $\begin{array}{c}14 \\
(34.1 \%)\end{array}$ & $\begin{array}{c}2 \\
(4.9 \%)\end{array}$ \\
\hline 3. How hard you try & $\begin{array}{c}27 \\
(65.9 \%)\end{array}$ & $\begin{array}{c}11 \\
(26.8 \%)\end{array}$ & $3(7.3 \%)$ & - \\
\hline 4. Circumstances & $\begin{array}{c}1 \\
(2.4 \%)\end{array}$ & $\begin{array}{c}17 \\
(41.5 \%)\end{array}$ & $\begin{array}{c}20 \\
(48.8 \%)\end{array}$ & $\begin{array}{c}3 \\
(7.3 \%)\end{array}$ \\
\hline 5. Time & $\begin{array}{c}10 \\
(24.4 \%)\end{array}$ & $16(39 \%)$ & 14 & 1 \\
$(34.2 \%)$ & $(2.4 \%)$ \\
\hline 6. Interest & $\begin{array}{c}26 \\
(63.4 \%)\end{array}$ & $\begin{array}{c}13 \\
(31.7 \%)\end{array}$ & $2(4.9 \%)$ & - \\
\hline $\begin{array}{l}\text { 7. Way in which you } \\
\text { learn }\end{array}$ & $\begin{array}{c}17 \\
(41.5 \%)\end{array}$ & $\begin{array}{c}20 \\
(48.8 \%)\end{array}$ & $4(9.8 \%)$ & - \\
\hline $\begin{array}{l}\text { 8. Language learning } \\
\text { proficiency }\end{array}$ & $\begin{array}{c}8 \\
(19.5 \%)\end{array}$ & $\begin{array}{c}22 \\
(53.7 \%)\end{array}$ & $\begin{array}{c}10 \\
(24.4 \%)\end{array}$ & $\begin{array}{c}1 \\
(2.4 \%)\end{array}$ \\
\hline
\end{tabular}

The difficulty of a given task is often beyond a student's control. In this survey, however, eight (19.5\%) people assumed that they could completely control the difficulty of a task. Additionally, as many as seventeen (41.5\%) believed that the difficulty was often under their control. Fourteen (34.1\%) people said that they were not always able to control it, while two (4.9\%) believed that they had no influence over it.

Another aspect tested in the survey was the amount of effort put into learning, categorised in the third row of the table. Here, the results are not surprising. Twenty-seven (65.9\%) thought that they always had an impact on the effort. Eleven $(26.8 \%)$ believed that they could often control their effort, while three $(7.3 \%)$ believed that they could not influence it. Nobody chose the last option, "never".

When asked about the circumstances accompanying learning a second language, only one person $(2.4 \%)$ thought that 
they were always under his or her control, while seventeen $(41.5 \%)$ considered that they were quite often controllable. The most common response, with twenty respondents (48.8\%), was that they did not have any influence on external circumstances, and three $(7.3 \%)$ admitted that they never were able to control their circumstances.

The control over time devoted to learning was also part of the questionnaire. Ten $(24.4 \%)$ people claimed that the amount of time they spent on learning was always under their control, while sixteen (39\%) considered time as something frequently under their control. Fourteen (34.2\%) thought of time as an aspect not often under their control and one person $(2.4 \%)$ claimed that he or she was unable to control time devoted to learning.

Interest in the topic was essential for the majority of the students, as twenty-six (63.4\%) people claimed that it was always under their control. A smaller number of respondents, thirteen (31.7\%), considered interest as often under their control. Only two $(4.9 \%)$ students denied that their interest was something controllable.

Learning strategies, which students apply to boost the learning process, were considered by seventeen $(41.5 \%)$ as always under their control and by twenty (48.8\%) as often controllable. The reason behind such high results may be the individual approach to the matter of learning. Students tend to create a variety of ways to enhance their learning experience, and these are, in most cases, adequate for their skills and abilities.

As far as the last choice, "proficiency" is considered, it was thought to be always under control by eight (19.5\%) students, however, twenty-two (53.7 \%) perceived it as quite often manageable. Ten (24.4\%) believed that they were generally not able to control proficiency and, at the same time, only one $(2.4 \%)$ claimed that this control was unreachable. Summing up, even if the respondents are generally neither internally, nor externally oriented, when it comes to control over their academic 
achievements they tend to perceive causes as mainly controllable.

\subsubsection{Interviews}

Another tool used in the study was an interview with a few internals and externals to collect opinions from these two different groups. Unfortunately, the attempt to talk with people who showed a greater tendency to be external failed. As the questionnaire was anonymous, it was impossible to determine who had obtained the highest results indicating externality of control, moreover, apparently externally-oriented participants were unwilling to discuss their answers.

Eventually, it was decided to interview two subjects chosen at random, a woman and a man, who were willing to talk about their impressions related to the survey and to learning a second language. Incidentally, they were both internally-oriented. Both of them were very open and willing to share their thoughts, which may resonate with an internal LOC. Additionally, they were successful foreign language learners, able to focus on their academic work, ambitious and gained high marks during their studies.

Their answers indicated that they were able to focus on learning, which was their priority, analyse their mistakes and, in the event of failure, draw conclusions to avoid making the same mistakes in the future. In the case of morally ambiguous or demanding questions from the questionnaire, they were capable of choosing those which suited them best in terms of their personality traits and beliefs, which indicates a high level of autonomy. They also attributed a great deal of importance to their interest in the subject as well as to the potential benefits it can give. They declared themselves to be intrigued by the topics that seemed interesting to them and were ready to devote much more time to familiarize themselves with the issues that were not only interesting, but also useful in the future. The speakers placed great emphasis on their abilities, at the same time discussing 
how much they depended on them personally and their involvement.

When it comes to the strategy of learning, both of them emphasized the importance of creating a perfect learning environment to improve the effectiveness of the process. For the male participant, the most important strategy was working in silence, where he could focus on a given topic, while for the female participant, the ideal strategy was connected with her self-motivation to work harder. Both of them thought that favourable conditions for learning were necessary to achieve good results.

\section{Discussion}

It cannot be unambiguously determined that all of the study participants are internals, who attach great importance to achieving success due to their virtues. The results are almost equally distributed, with comparable numbers of people showing inclinations to be internal, external, and in the middle. No extreme choices were observed.

As previously mentioned, a similar study was carried out by Biedron in 2003 (see also 2008) on a group of English philology students with a similar number of subjects. The overall results of both studies are very similar, in that they indicate that the students are rather internally oriented when considering their academic achievements related to learning a foreign language. The students regard most factors as being under their personal control, even those that are hardly controllable, for example external factors or internally situated stable features such as aptitude. Small differences between those two studies were noticeable in only two items, namely in the perception of abilities and the difficulty of a given task. When compared to their counterparts from 2003, students from 2019 attribute even more control to seemingly uncontrollable factors, such as abilities or task difficulty. Although this perspective must be perceived as very unrealistic or even naive, it portrays English philology students as success-oriented and quite autonomous foreign language 
learners. This also confirms that the perception of factors in foreign language learning as controllable is a significant variable in achieving success in SLA (Biedron 2008: 114). Therefore, it can be stated that students from 2019 do not differ much from their counterparts from 2003 in their LOC. Students who choose an advanced path of education at a university must display at least some features that are typical of internals. As a result, they are able to achieve success and cope with difficult situations, while at the same time developing their language skills. This does not mean, however, that people with external LOC are doomed to fail. Their approach to certain matters related to learning is simply different. In contrast to the internals, who strongly believe in their skills, externally-oriented people pay more attention to their failures and blame others for unsuccessful outcomes.

In the interviews that took place with two participants a similar approach is visible. These short conversations also contributed to a better understanding of the whole issue of perceived control. The academic achievements of the speakers were quite high, confirmed by good marks obtained during their studies. Their responses clearly indicated an internal LOC, as the speakers put great emphasis on their skills, considering themselves to be responsible for their successes and academic achievements.

\section{Conclusions}

The purpose of this study was to investigate the level of LOC among English philology undergraduates as compared to those from 2003. It was important to investigate whether students were internal in their beliefs, meaning that they were able not only to focus on their skills and abilities to achieve better academic results, but also to attribute more significance to the factors that depend on them.

The results presented in this paper clearly show that it is impossible to classify every English philology student as either 
clearly internal or external, as the large majority of them were almost in the middle of the continuum. This indicates that the students are aware that in order to achieve academic success they need to focus on their skills, strategies and abilities, and not on external factors, yet they are cognizant that not everything can be controlled. It seems that they understand the complex relationship between the reality they live in and the goals that they could achieve by focusing on their own experiences and capabilities. It is also worth mentioning that in most cases the respondents' answers were intuitive and subjective. This is evident, for example, in the case of the question about the capacity to control one's abilities, which is objectively impossible. The affirmative answer indicates that, probably, they look at their own capabilities through the prism of their personal habits or beliefs which sometimes makes a correct judgement of the situation impossible.

The main limitation of the study was the small number of respondents, as well as their homogeneity. In future there should be more answers from which more detailed and reliable conclusions could be drawn, especially in interviews. Furthermore, a larger number of people from different spectra, both internal and external, would allow for a much more detailed description of the results, and offer a better insight into the beliefs and motivation of students.

Summing up, both modern students from 2019, and the group Biedron studied in 2003 have a convergent approach to the way they learn and see themselves as responsible for their own successes and failures while studying. The similarity of the results suggests that the two groups of students' views and motivations connected with learning are rather comparable and have not changed dramatically over the years. Yet, in order to draw any far-reaching conclusions, another study on a larger and more diversified population is needed in the future. 


\section{References}

Biedroń, Adriana (2003). Attribution related affects as a function of perceived causality of academic success or failure among successful foreign language learners. Unpublished doctoral dissertation. Adam Mickiewicz University in Poznań.

Biedroń, Adriana (2008). Attribution Related Affects in Second Language Acquisition. Słupsk: Wydawnictwo Naukowe Akademii Pomorskiej w Słupsku.

Carver, Charles S. (1976). "Attribution of success as a function of locus of control and objective self-awareness". Bulletin of the Psychonomic Society 7/4: 358-360.

Davis, William L., Elaine D. Davis (1972). "Internal-external control and attribution of responsibility for success and failure". Journal of Personality 40/1: 123-136.

Gałazka, Alicja, Magdalena Trinder (2016). "Locus of control and receptive skills in second language acquisition". The New Educational Review 46: 130-141.

Heider, Fritz (1958). The Psychology of Interpersonal Relations. New York: Wiley.

Kelley, Harold H. (1973). "The processes of causal attribution". American Psychologist 28/2: 107-128.

Munton, Anthony G., Joanne Silvester, Peter Stratton, Helga Hanks (1999). Attributions in Action. A Practical Approach to Coding Qualitative Data. Chichester: Wiley.

Özen Kutanis, Rana, Muammar Mesci, Zeynep Övdür (2011). "The effects of locus of control on learning performance: A case of an academic organization". Journal of Economic and Social Studies 1/2: 113-136.

Patterson, Ian (2018). Tourism and Leisure Behaviour in an Ageing World. Wallingford: CABI.

Phares, Jerry E. (1957). "Expectancy changes in skill and chance situations". The Journal of Abnormal and Social Psychology 54/3: 339-342.

Phares, Jerry E., Kenneth G. Wilson, Nelson W. Klyver (1971). "Internal-external control and the attribution of blame under neutral and distractive conditions". Journal of Personality and Social Psychology 18/3: 285-288. 
Rotter, Julian B. (1966). "Generalised expectancies for internal versus external locus of control of reinforcement". Psychological Monographs 80: 489-493.

Strickland, Bonnie R. (1977). "Internal-external control of reinforcement". In: Thomas Blass (2015). Personality Variables in Social Behaviour. New York: Psychology Press, 219-280.

Weiner, Bernard (1985). "An attributional theory of motivation and emotion". Psychological Review 92/4: 548-573.

Williams, Marion, Robert L. Burden (1997). Psychology for Language Teachers: a Social Constructivist Approach. Cambridge: CUP.

Wong, Paul T. P., Catherine F. Sproule (1984). "An attribution analysis of the locus of control construct and the Trent Attribution Profile". In Herbert M. Lefcourt (ed.). Research with the Locus of Control construct: Extensions and Limitations. Vol. 3. New York: Academic Press, 309-360.

\section{Appendices}

\section{APPENDIX A}

\section{ROTTER'S LOCUS OF CONTROL SCALE}

1. a. Children get into trouble because their patents punish them too much.

b. The trouble with most children nowadays is that their parents are too easy with them.

2. a. Many of the unhappy things in people's lives are partly due to bad luck.

b. People's misfortunes result from the mistakes they make.

3. a. One of the major reasons why we have wars is because people don't take enough interest in politics.

b. There will always be wars, no matter how hard people try to prevent them.

4. a. In the long run people get the respect they deserve in this world.

b. Unfortunately, an individual's worth often passes unrecognized no matter how hard he tries

5. a. The idea that teachers are unfair to students is nonsense. 
b. Most students don't realize the extent to which their grades are influenced by accidental happenings.

6. a. Without the right breaks one cannot be an effective leader.

b. Capable people who fail to become leaders have not taken advantage of their opportunities.

7. a. No matter how hard you try some people just don't like you.

b. People who can't get others to like them don't understand how to get along with others.

8. a. Heredity plays the major role in determining one's personality.

b. It is one's experiences in life which determine what they're like.

9. a. I have often found that what is going to happen will happen.

b. Trusting to fate has never turned out as well for me as making a decision to take a definite course of action.

10. a. In the case of the well prepared student there is rarely if ever such a thing as an unfair test.

b. Many times exam questions tend to be so unrelated to course work that studying in really useless.

11. a. Becoming a success is a matter of hard work, luck has little or nothing to do with it.

b. Getting a good job depends mainly on being in the right place at the right time.

12. a. The average citizen can have an influence in government decisions.

b. This world is run by the few people in power, and there is not much the little guy can do about it.

13. a. When I make plans, I am almost certain that I can make them work.

b. It is not always wise to plan too far ahead because many things turn out to- be a matter of good or bad fortune anyhow.

14. a. There are certain people who are just no good.

b. There is some good in everybody.

15. a. In my case getting what I want has little or nothing to do with luck.

b. Many times we might just as well decide what to do by flipping a coin.

16. a. Who gets to be the boss often depends on who was lucky enough to be in the right place first. 
b. Getting people to do the right thing depends upon ability. Luck has little or nothing to do with it.

17. a. As far as world affairs are concerned, most of us are the victims of forces we can neither understand, nor control.

b. By taking an active part in political and social affairs the people can control world events.

18. a. Most people don't realize the extent to which their lives are controlled by accidental happenings.

b. There really is no such thing as "luck."

19. a. One should always be willing to admit mistakes.

b. It is usually best to cover up one's mistakes.

20. a. It is hard to know whether or not a person really likes you.

b. How many friends you have depends upon how nice a person you are.

21. a. In the long run the bad things that happen to us are balanced by the good ones.

b. Most misfortunes are the result of lack of ability, ignorance, laziness, or all three.

22. a. With enough effort we can wipe out political corruption.

b. It is difficult for people to have much control over the things politicians do in office.

23. a. Sometimes I can't understand how teachers arrive at the grades they give.

b. There is a direct connection between how hard 1 study and the grades I get.

24. a. A good leader expects people to decide for themselves what they should do.

b. A good leader makes it clear to everybody what their jobs are.

25. a. Many times I feel that I have little influence over the things that happen to me.

b. It is impossible for me to believe that chance or luck plays an important role in my life.

26. a. People are lonely because they don't try to be friendly.

b. There's not much use in trying too hard to please people, if they like you, they like you.

27. a. There is too much emphasis on athletics in high school.

b. Team sports are an excellent way to build character.

28. a. What happens to me is my own doing.

b. Sometimes I feel that I don't have enough control over the direction my life is taking. 
29. a. Most of the time I can't understand why politicians behave the way they do.

b. In the long run the people are responsible for bad government on a national as well as on a local level.

\section{APPENDIX B}

\section{Controllability dimension in foreign language learning}

Which of the following factors are within your own control when trying to learn a new language?

\begin{tabular}{|c|c|c|c|c|}
\hline & Always & $\begin{array}{l}\text { Quite } \\
\text { often }\end{array}$ & $\begin{array}{c}\text { Not of- } \\
\text { ten }\end{array}$ & Never \\
\hline Your ability & * & * & * & * \\
\hline Difficulty of a task & * & * & * & * \\
\hline How hard you try & * & * & * & * \\
\hline Circumstances & * & * & * & * \\
\hline Time & * & * & * & * \\
\hline Interest & * & * & * & * \\
\hline $\begin{array}{l}\text { Way in which you } \\
\text { learn }\end{array}$ & * & * & * & * \\
\hline $\begin{array}{l}\text { Language learning } \\
\text { proficiency }\end{array}$ & * & * & * & * \\
\hline
\end{tabular}




\section{APPENDIX C}

\section{INTERVIEW - QUESTIONS}

1. What made you choose those specific answers?

2. Did you choose answers you liked more or those you thought you "should" as they sound better?

3. What about the answers you were not sure about or you were not always able to agree with?

4. Do you think you have any influence on the quality/way of learning or is it not dependent on you?

5. What is important to you when you learn a second language, what do you pay attention to?

Paulina Ogórek

ORCID iD: 0000-0001-9247-6847

Pomeranian University in Słupsk

Department of English Studies

Słowiańska 8

76-200 Słupsk

Poland

paulina.ogorek@apsl.edu.pl

Adriana Biedroń

ORCID iD: 0000-0002-4382-0223

Pomeranian University in Słupsk

Department of English Studies

Słowiańska 8

76-200 Słupsk

Poland

adriana.biedron@apsl.edu.pl 